\title{
Heterologous expression of heterotrophic nitrification genes
}

\author{
Lisa C. Crossman, James W. B. Moir,† Julie J. Enticknap,‡ \\ David J. Richardson and Stephen Spiro
}

Author for correspondence: Stephen Spiro. Tel: +44 1603 592777. Fax: +44 1603592250.

e-mail: s.spiro@uea.ac.uk

School of Biological Sciences, University of East Anglia, Norwich NR4 7TJ, UK

\begin{abstract}
Paracoccus denitrificans is a heterotrophic organism capable of oxidizing ammonia to nitrite during growth on an organic carbon and energy source. This pathway, termed heterotrophic nitrification, requires the concerted action of an ammonia monooxygenase (AMO) and hydroxylamine oxidase (HAO). The genes required for heterotrophic nitrification have been isolated by introducing a Pa. denitrificans genomic library into Pseudomonas putida and screening for the accumulation of nitrite. In contrast to the situation in chemolithoautotrophic ammonia oxidizers, the genes encoding AMO and HAO are present in single linked copies in the genome of Pa. denitrificans. AMO from Pa. denitrificans expressed in Ps. putida is capable of oxidizing ethene (ethylene) to epoxyethane (ethylene oxide), which is indicative of a relaxed substrate specificity. Further, when expressed in the methylotroph Methylobacterium extorquens AM1, the AMO endows on this organism the ability to grow on ethene and methane. Thus, the Pa. denitrificans AMO is capable of oxidizing methane to methanol, as is the case for the AMO from Nitrosomonas europaea. The heterotrophic nitrification genes are moderately toxic in M. extorquens, more toxic in Ps. putida, and non-toxic in Escherichia coli. Toxicity is due to the activity of the gene products in $M$. extorquens, and both expression and activity in Ps. putida. This is the first time that the genes encoding an active AMO have been expressed in a heterologous host.
\end{abstract}

Keywords: heterotrophic nitrification, ammonia monooxygenase, hydroxylamine oxidoreductase, Paracoccus denitrificans, Methylobacterium extorquens

\section{INTRODUCTION}

Chemolithoautotrophic nitrifying bacteria such as Nitrosomonas europaea derive energy for growth from the oxidation of ammonia to nitrite (Bock et al., 1991). Ammonia is first oxidized to hydroxylamine in a reaction catalysed by ammonia monooxygenase (AMO), and hydroxylamine is subsequently oxidized to nitrite by hydroxylamine oxidase (also known as hydroxylamine oxidoreductase; HAO). Some heterotrophic bacteria are also capable of nitrification, in an analogous process which is less well understood. The

\footnotetext{
†Present address: Department of Molecular Biology and Biotechnology University of Sheffield, Sheffield S10 2TN, UK.

$\ddagger$ Present address: Department of Biological Sciences, University of Warwick, Coventry CV4 7AL, UK.

Abbreviations: AMO, ammonia monooxygenase; HAO, hydroxylamine oxidase; $\mathrm{PMMO}$, particulate methane monooxygenase.
}

physiological role of heterotrophic nitrification is somewhat obscure, but it is believed to be involved in the dissipation of excess reductant (Robertson \& Kuenen, 1988; Wehrfritz et al., 1993). Heterotrophic nitrification may be linked to aerobic denitrification, such that the nitrite produced by nitrification is converted through nitric oxide and nitrous oxide to dinitrogen (Robertson \& Kuenen, 1990a, b; Wehrfritz et al., 1993). The $\alpha$ proteobacterium Paracoccus denitrificans GB17 (formerly known as Thiosphaera pantotropha) has previously been reported to be capable of heterotrophic nitrification (Robertson \& Kuenen, 1983, 1988).

The biochemistry of nitrification has been extensively studied in chemolithoautotrophs, especially $N$. europaea. The AMO of $N$. europaea is a membranebound enzyme which has extensive sequence similarity to the particulate methane monooxygenases (pMMOs) of methanotrophic bacteria (Semrau et al., 1995; Holmes et al., 1995). Both enzymes contain copper at the 
active site, which may be arranged as a trinuclear centre (Ensign et al., 1993; Nguyen et al., 1994, 1996) The pMMO has recently been purified from Methylococcus capsulatus (Bath) and reported to be a three-subunit enzyme that also contains iron (Zahn \& DiSpirito, 1996). Genes designated $p m o A$ and $p m o B$ have been characterized, and the nucleotide sequence of a third gene, $p m o C$, is described in the sequence databases (Semrau et al., 1995; Zahn \& DiSpirito, 1996; accession numbers L40804 and U94337). The AMO is also believed to be encoded by three genes, amo $A, a m o B$ and amoC, of which there are two copies each in the N. europaea genome (McTavish et al., 1993a, b; Klotz et al., 1997). The AMOs and pMMOs have broad substrate specificities; they are capable of oxidizing ammonia, methane, short-chain alkanes, alkenes and chlorinated hydrocarbons, as well as catalysing the hydroxylation of aromatic compounds (Burrows et al., 1984; Hyman \& Wood, 1984; Keener \& Arp, 1994).

The hydroxylamine cytochrome $c$ oxidoreductase of $N$. europaea is a complex trimer of $63 \mathrm{kDa}$ subunits each containing eight haems, including an unusual $\mathrm{P} 460$ haem (Arciero \& Hooper, 1993; Arciero et al., 1993; Igarashi et al., 1997). N. europaea also expresses another, distinct, cytochrome $\mathrm{P} 460$ with $\mathrm{HAO}$ activity, analogous to that of Methylococcus capsulatus (Bergmann \& Hooper, 1994a; Zahn et al., 1994). In contrast, the HAO from $\mathrm{Pa}$. denitrificans is a monomeric protein of approximately $18.5 \mathrm{kDa}$ containing non-haem iron (Wehrfritz et al., 1993; Moir et al., 1996a). The hao gene of $N$. europaea has been characterized and is closely linked to the $b c y$ gene encoding cytochrome $c_{554}$, which may be the primary electron acceptor for HAO (Hommes et al., 1994; Sayavedra-Soto et al., 1994; Arciero et al., 1991). Three copies each of the hao and hcy genes are present in the $N$. europaea genome (McTavish et al., 1993a).

It is of considerable interest to understand the biochemistry of heterotrophic nitrification, which appears to be different to that of autotrophic nitrification. Ultimately, it is also important to estimate the impact of heterotrophic nitrification on the global nitrogen cycle. The present communication reports the cloning of the heterotrophic nitrification genes from $\mathrm{Pa}$. denitrificans and their expression in the heterologous hosts Pseudomonas putida and Methylobacterium extorquens AM1.

\section{METHODS}

Bacterial strains and plasmids. Pa. denitrificans Pd1222 was obtained from N. Harms (Vrije Universiteit, Amsterdam), and M. extorquens AM1 ATCC 14718 from M. D. Page (University of Oxford). Other strains used were Ps. putida ATCC 12633, and E. coli strains HB101 [supE44 hsdS2O $\left(\mathrm{r}_{\mathrm{b}}{ }^{-} \mathrm{m}_{\mathrm{b}}{ }^{-}\right)$ recA13 ara14 proA2 lacY1 galK2 rpsL20 xyl5 mtl1], JM101 $\left\{\right.$ supE thi $\Delta\left(\right.$ lac-proAB) $\mathrm{F}^{\prime}\left[\right.$ traD36 proAB ${ }^{+}$lacl ${ }^{a}$ lac $\left.\mathrm{Z} \Delta \mathrm{M} 15\right]$, 803 [met], DH5 $\alpha$ [supE44 $\Delta$ lacU169 ( $\phi 80$ lacZ $\Delta$ M15) hsdR17 recA1 endA1 gyrA96 thi1 relA1] and S17-1 [thi pro hsdR recA RP4-2 integrated Tc::Mu Km::Tn7]. Plasmids used were pUC18 (Yanisch-Perron et al., 1985), the broad-host-range cosmids pLAFR3 and pLAFR5 (Staskawicz et al., 1987; Keen et al., 1988), pRK2013 (Figurski \& Helinski, 1979) and pGRPd1 (van Spanning et al., 1991).

Pa. denitrificans was grown at $30^{\circ} \mathrm{C}$ either in LB medium $(10 \mathrm{~g}$ tryptone $1^{-1}, 5 \mathrm{~g}$ yeast extract $\mathrm{l}^{-1}, 10 \mathrm{~g} \mathrm{NaCl}^{-1}$ ) or on the minimal medium of Harms et al. (1985). Ps. putida and $M$. extorquens were grown at $30^{\circ} \mathrm{C}$ in $\mathrm{LB}$, or on minimal phosphate medium (Robertson \& Kuenen, 1988). E. coli strains were grown in LB at $37^{\circ} \mathrm{C}$. Liquid cultures were grown in $50 \mathrm{ml}$ medium in $250 \mathrm{ml}$ flasks shaken at 200 r.p.m. Growth on methane was on solid medium in a gas jar containing a $50 \%(\mathrm{v} / \mathrm{v})$ mix of methane and air. Growth on ethene was in $20 \mathrm{ml}$ bottles fitted with gas-tight lids and shaken at 200 r.p.m., and growth on methanol was in minimal phosphate medium containing $1 \%(\mathrm{v} / \mathrm{v})$ methanol. Antibiotics were added to growth media as appropriate: kanamycin $\left(200 \mu \mathrm{g} \mathrm{ml}^{-1}\right)$, ampicillin $\left(200 \mu \mathrm{g} \mathrm{ml}^{-1}\right.$ for E. coli, $50 \mu \mathrm{g} \mathrm{ml}^{-1}$ for Ps. putida) and tetracycline $\left(12.5 \mu \mathrm{g} \mathrm{ml}^{-1}\right.$ for E. coli, M. extorquens and Ps. putida, $1 \mu \mathrm{g} \mathrm{ml}^{-1}$ for Pa. denitrificans).

Analytical methods. Nitrite was assayed colorimetrically using the overlay technique of Glaser \& DeMoss (1971) on solid medium and the method of Coleman et al. (1978) in liquid medium. Gas chromatography was carried out on a Unicam gas chromatograph fitted with a Hayesep Q column (Supelco) maintained at $120^{\circ} \mathrm{C}$; the carrier gas was $\mathrm{N}_{2}$ at a flow rate of $30 \mathrm{ml} \mathrm{min}^{-1}$. The injector was maintained at $200^{\circ} \mathrm{C}$ and detection was by flame ionization at $325^{\circ} \mathrm{C}$ in $\mathrm{H}_{2}$ $\left(33 \mathrm{ml} \mathrm{min}^{-1}\right)$ and air $\left(300 \mathrm{ml} \mathrm{min}^{-1}\right)$. The system was calibrated by injection of a known amount of epoxyethane, and epoxyethane in samples was estimated by integration. Cultures were incubated overnight in the presence of ethene in sealed vessels shaken at 200 r.p.m. in the dark at $30^{\circ} \mathrm{C}$, and were then heated to $80^{\circ} \mathrm{C}$ for $10 \mathrm{~min}$ prior to sampling $100 \mu \mathrm{l}$ headspace gas. The corresponding concentration of epoxyethane in the solution phase was calculated on the assumption that it is a standard gas at room temperature and pressure. Nitrate reductase activity was assayed and cells were fractionated as described by Bell et al. (1990). Protein concentrations were estimated using the Bradford (1976) method.

Immunological methods. To raise antibodies to HAO, the protein was purified according to Wehrfritz et al. (1993) and conjugated to bovine serum albumin. Antibodies were raised in sheep by Immunogen International. Western blotting was carried out following a modification of the method of Burnette (1981), using a Pharmacia Novoblot apparatus. The secondary antibody was donkey anti-sheep conjugated to alkaline phosphatase (Sigma). Blots were developed in $10 \mathrm{ml} 100 \mathrm{mM}$ Tris/ $\mathrm{HCl}, 100 \mathrm{mM} \mathrm{NaCl}$ and $50 \mathrm{mM} \mathrm{MgCl}_{2}$ (pH 9.5) containing $40 \mu \mathrm{l}\left(75 \mathrm{mg} \mathrm{ml}^{-1}\right)$ nitro blue tetrazolium and $40 \mu \mathrm{l}$ (50 $\mathrm{mg} \mathrm{ml}^{-1}$ ) 5-bromo-4-chloro-3-indolyl phosphate.

DNA manipulation: library construction and transfer to Ps. putida. Routine DNA manipulations were performed according to Sambrook et al. (1989). A genomic library of $\mathrm{Pa}$. denitrificans Pd1222 was constructed in the broad-host-range cosmid vector pLAFR3. Genomic DNA was subjected to partial digestion with $\mathrm{Mbol}$ and digestion products of approximately $20-25 \mathrm{~kb}$ were purified by sucrose gradient centrifugation (Sambrook et al., 1989) and ligated into Bam HIdigested and dephosphorylated pLAFR3. The ligation reaction was packaged in vitro using a Gigapack packaging extract (Stratagene) and infected into HB101. The Pa. denitrificans library was then introduced en masse into Ps. putida by a triparental mating utilizing the helper strain $E$. coli $803 /$ pRK2013. Overnight cultures $(50 \mathrm{ml})$ of HB101 carrying the library, 803/pRK2013 and Ps. putida were harvested, 
washed in $\mathrm{LB}$, resuspended in $\mathrm{LB}$, mixed, placed onto a sterile nitrocellulose filter on $\mathrm{LB}$ agar, and incubated overnight at $30^{\circ} \mathrm{C}$. The filter was then washed in LB and the mating mixture was diluted and plated for single colonies on LB agar containing tetracycline and ampicillin (Ps. putida is naturally ampicillin resistant, allowing counter-selection against the $E$. coli donors). Colonies were picked with sterile toothpicks and plated in duplicate on minimal media with succinate and ammonia as carbon and nitrogen sources, respectively. After growth for $3 \mathrm{~d}$ at $30^{\circ} \mathrm{C}$, colonies were tested with the colorimetric nitrite plate overlay assay. Positives for nitrite accumulation were picked from the stock plate for further analysis.

DNA:DNA hybridization. Using the published amo $A B$ sequence (McTavish et al., 1993b), primers were designed for the amplification of part of the coding region of $a m o B$ (from nucleotides 1080 to 1659 , corresponding to an $\mathrm{N}$-terminal fragment ending at Gly-95). These primers were used in PCRs with $N$. europaea genomic DNA as the template, and the amplification product was cloned into pUC18. Restriction digests of Pa. denitrificans DNA were transferred to filters by Southern blotting, and were hybridized with the ${ }^{32} \mathrm{P}$-labelled $a m o B$ probe. Hybridization was at $30^{\circ} \mathrm{C}$ overnight, and filters were washed for $2 \times 5 \mathrm{~min}$ in $6 \times \mathrm{SSC}$ at room temperature, and developed by autoradiography (Sambrook et al., 1989).

\section{RESULTS AND DISCUSSION}

\section{Cloning of heterotrophic nitrification genes in Ps. putida}

Nitrite accumulation was chosen as an indicator of heterotrophic nitrification because there is a sensitive colorimetric assay for nitrite which can be carried out both in liquid culture and on solid media. Ps. putida ATCC 12633 was used as the host organism for cloning, since it does not express nitrification or denitrification pathways (unpublished results). Therefore, it was anticipated that the introduction of an ability to nitrify would cause nitrite to accumulate to a detectable level. A $\mathrm{Pa}$. denitrificans genomic library was introduced into Ps. putida and exconjugants capable of nitrite accumulation were selected. Altogether, 25 cosmids which fell into three classes were independently isolated by this procedure (Table 1). The first class, exemplified by pB110, conferred on Ps. putida reduced methyl viologen dependent nitrate and chlorate reductase activities (Table 1), which localized to the membrane fraction and were sensitive to inhibition by azide (data not shown). This suggests that pB110 carries the genes for the membrane-bound respiratory nitrate reductase of $\mathrm{Pa}$. denitrificans, an enzyme which characteristically also reduces chlorate and is sensitive to azide (Berks et al., 1995). This was confirmed by demonstrating hybridization between $\mathrm{pB} 110$ and the narH gene encoding the $\beta$-subunit of the enzyme. The second class of cosmids, exemplified by pL110, also conferred a reduced methyl viologen dependent nitrate reductase activity on Ps. putida but no detectable chlorate reductase activity (Table 1 ). In this case, nitrate reductase activity was localized in the periplasmic fraction and was insensitive to inhibition by $20 \mu \mathrm{M}$ azide (data not shown). This is consistent with pL110 carrying the genes for the soluble periplasmic nitrate reductase of $\mathrm{Pa}$. denitrificans, which does not reduce chlorate and is insensitive to azide (Berks et al., 1995). This was confirmed by hybridization with the napA gene encoding the catalytic subunit of the enzyme. Although no nitrate was added to the media used for the isolation of the pB110-type cosmids, it is likely that the ability of the membrane-bound nitrate reductase to reduce trace amounts of nitrate in the media accounts for the isolation of these cosmids using the nitrite accumulation assay. By contrast, cosmids of the pL110 class were only isolated in subsequent experiments in which nitrate was added to growth media. This procedure may be generally applicable as a means of cloning nitrate reductase genes. The 24 cosmids of the $\mathrm{pB} 110$ and pL110 classes were isolated from a total of approximately 15000 exconjugants.

Approximately 5000 exconjugants were incubated for $3 \mathrm{~d}$ prior to the nitrite overlay assay (rather than the overnight incubation used in the isolation of nitrate reductase clones). A single cosmid belonging to a third class, designated pLCC5, was isolated by this procedure, and it conferred on Ps. putida the ability to accumulate nitrite slowly and to low levels. The $3 \mathrm{~d}$ incubation period was necessary for nitrite to accumulate to detectable levels in the Ps. putida/pLCC5 exconjugant.

Table 1. Properties of cosmids isolated from Ps. putida exconjugants which accumulate nitrite

\begin{tabular}{|c|c|c|c|c|c|c|c|}
\hline \multirow[t]{2}{*}{ Cosmid } & \multirow{2}{*}{$\begin{array}{l}\text { Nitrate reductase } \\
\left(\mathrm{nmol} \mathrm{min}^{-1} \mathrm{mg}^{-1}\right)^{*}\end{array}$} & \multirow{2}{*}{$\begin{array}{l}\text { Chlorate reductase } \\
\left(\mathrm{nmol} \mathrm{min}^{-1} \mathrm{mg}^{-1}\right)^{*}\end{array}$} & \multirow{2}{*}{$\begin{array}{c}\text { Nitrate } \\
\text { induction of } \\
\text { nitrite } \\
\text { production }\end{array}$} & \multirow{2}{*}{$\begin{array}{c}\text { Nitrite } \\
\text { accumulation } \\
\text { in absence of } \\
\text { ammonia }\end{array}$} & \multicolumn{2}{|c|}{ Hybridization $\dagger$} & \multirow{2}{*}{$\begin{array}{l}\text { Cross- } \\
\text { reaction to } \\
\text { anti-HAO }\end{array}$} \\
\hline & & & & & narH & $\operatorname{nap} A$ & \\
\hline pB110 & 1270 & 4780 & + & + & + & - & - \\
\hline pL110 & 3300 & ND & + & + & - & + & - \\
\hline
\end{tabular}

* Cells were disrupted by sonication; reduced methyl viologen dependent nitrate and chlorate reductase activities were determined in duplicate as described by Bell et al. (1990) and are expressed as nmol methyl viologen oxidized min $^{-1}$ (mg protein) ${ }^{-1}$. ND, Not detectable. Data are from assays of two independent cultures.

† Hybridization experiments were performed using probes for the structural genes for the Pa. denitrificans membrane-bound (narH) and periplasmic (napA) nitrate reductases. 
2

3

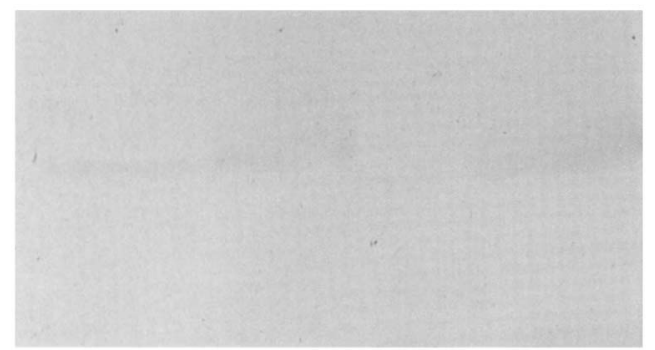

Fig. 1. Immunological detection of $P$ a. denitrificans $\mathrm{HAO}$ expressed in Ps. putida. Pure HAO and cell-free extracts from the strains indicated were separated by SDS-PAGE, transferred to a nitrocellulose membrane and analysed with an anti-HAO antiserum. Lanes: 1, pure HAO; 2, Pa. denitrificans; 3, Ps. putida; 4, Ps. putida/pLCC5.

There was no detectable nitrate reductase activity in whole cells or cellular fractions of Ps. putida/pLCC5. This strain did not accumulate nitrite in the absence of ammonia, and the addition of nitrate to the medium did not affect levels of nitrite production. These observations suggest that nitrite accumulation by $P s$. putida/pLCC5 was a consequence of ammonia oxidation rather than nitrate reduction. Cell-free extracts of Ps. putida/pLAFR3 and Ps. putida/pLCC5 were separated by SDS-PAGE, transferred to nitrocellulose membranes and analysed with a polyclonal antiserum raised against the $P a$. denitrificans hydroxylamine oxidoreductase (Fig. 1). An $18.5 \mathrm{kDa}$ polypeptide which reacted with anti-HAO was clearly detectable in extracts of Ps. putida/pLCC5 but not in Ps. putida/pLAFR3. Thus pLCC5 carries the gene(s) encoding HAO, and since it confers the ability to oxidize ammonia to nitrite, it is very likely that it also carries the genes for AMO. This was confirmed by demonstrating that the introduction of pLCC5 into Pa. denitrificans caused a marked increase in AMO activity; indeed this strain provided a suitable source for the purification of the enzyme (Moir et al., 1996b). Thus there is strong evidence that pLCC5 carries all of the $\mathrm{Pa}$. denitrificans genes required for the oxidation of ammonia to nitrite. The reason why only a single cosmid expressing nitrification genes could be isolated is not clear at the present time, but may relate to the toxicity that is associated with some nitrification clones (see below).

\section{Ethene oxidation}

The AMO of $N$. europaea and the pMMO of Metbylococcus capsulatus (Bath) both have a broad substrate range and are capable of oxidizing ammonia, methane, short-chain alkanes and alkenes, dehalogenating short-chain halogenated hydrocarbons and catalysing the hydroxylation of aromatic compounds (Burrows et al., 1984; Hyman \& Wood, 1984; Keener \& Arp, 1994). The pMMO of Methylococcus capsulatus (Bath) is routinely assayed by following the production of propene oxide from propene (Colby et al., 1977;
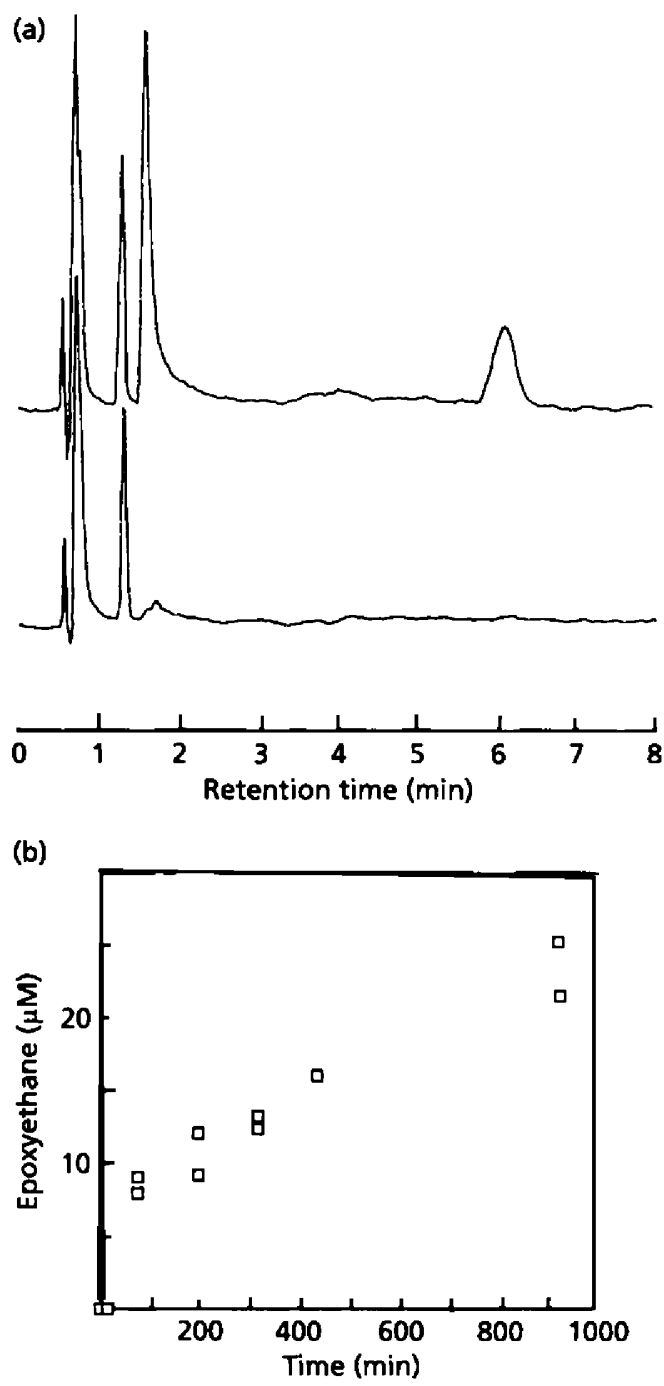

Fig. 2. (a) Oxidation of ethene to epoxyethane by Ps. putida/pLCC5. Washed cell suspensions were incubated in the presence of ethene, and the headspace was analysed by gas chromatography. The peak with a retention time of approximately $6 \mathrm{~min}$ is epoxyethane. Upper trace, Ps. putida/pLCC5; lower trace, Ps. putida/pLAFR3. The peak at approximately $2 \mathrm{~min}$ in the upper trace is an additional, unidentified, product of ethene oxidation (and is absent from control chromatograms of pure epoxyethane). Both this peak and the epoxyethane peak were absent from a control reaction containing ethene but no cells. (b) Time-course of epoxyethane accumulation by Ps. putida/pLCC5. Cell suspensions from two independent cultures incubated in the presence of ethene were sampled at time intervals and analysed as in (a).

Stirling \& Dalton, 1979). Ethene oxidation can be detected in $\mathrm{Pa}$. denitrificans by monitoring the production of epoxyethane (see below). To determine whether ethene oxidation is due to the activity of AMO, the AMO of $P a$. denitrificans expressed in Ps. putida was tested for the ability to oxidize ethene. Washed cells of $P s$. putida/pLCC5 and Ps. putida/pLAFR3 were incubated overnight in sealed vessels in phosphate buffer containing approximately $500 \mu \mathrm{M}$ ethene. The headspace was then sampled and analysed by gas chromato- 


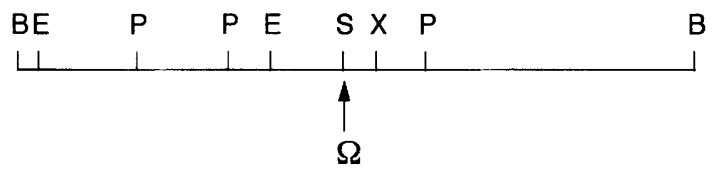

pB8

Fig. 3. Partial restriction map of the insert in $\mathrm{pB} 8$ which confers AMO activity in Ps. putida. The EcoRI-Pstl fragment which hybridizes weakly to the $N$. europaea $a m o B$ gene is indicated, as is the Sall site at which the Pa. denitrificans chromosome was disrupted. B, BamHI; E, EcoRI; P, Pstl; S, Sall; X, Xhol.

graphy (Fig. 2a). Epoxyethane was produced from ethene by Ps. putida/pLCC5 but not by $P$ s. putida/pLAFR3. In time-course experiments, washed cells of Ps. putida/pLCC5 showed an initial rapid burst of epoxyethane production, followed by a linear accumulation, such that $20 \mu \mathrm{M}$ epoxyethane accumulated over a period of $15 \mathrm{~h}$ (Fig. 2b). Disrupted cells of $P s$. putida/pLCC5 prepared by sonication and incubated with ethene produced epoxyethane at broadly similar rates as did whole cells. However, in the presence of the copper chelator diethyldithiocarbamate $(1 \mathrm{mM})$, epoxyethane was not produced from ethene by disrupted cells. This suggests that the AMO of Pa. denitrificans is a copper-containing enzyme capable of oxidizing alkenes, as are the AMOs of the autotrophic nitrifiers and the pMMOs of the methanotrophs. The behaviour of pLCC5 with regard to ethene oxidation provides further evidence that this plasmid contains genes involved in ammonia oxidation.

\section{Disruption of the Pa. denitrificans nitrification genes}

Restriction fragments derived from the insert of pLCC5 were ligated into pLAFR5, transformed into E. coli and then introduced directly into Ps. putida by conjugation. In this manner, an $8 \mathrm{~kb}$ Bam HI fragment was identified (in a pLAFR 5 derivative designated pB8; Fig. 3) which conferred AMO activity, as judged by ethene oxidation and the accumulation of nitrite during growth. Furthermore, $P_{s}$. putida/pB8 showed an ammonia-dependent oxygen uptake activity $\left(3.7 \mathrm{nmol} \mathrm{O}_{2} \mathrm{~min}^{-1} \mathrm{mg}^{-1}\right)$ which was sensitive to diethyldithiocarbamate and was not detectable in the wild-type strain. However, cell-free extracts prepared from $P s$. putida $/ \mathrm{pB} 8$ showed no immunological cross-reaction with the anti-HAO antibody, suggesting that none or not all of the gene(s) encoding $\mathrm{HAO}$ are present on the insert in $\mathrm{pB} 8$. No other subclones were identified which conferred any nitrification activity, which may be because there are toxicity problems associated with the cloned nitrification genes (see below). The accumulation of nitrite in Ps. putida/pB8, which does not appear to synthesize HAO, may result from chemical oxidation of hydroxylamine to nitrite. Iron(III) ions oxidize hydroxylamine to $\mathrm{NOH}$, which under aerobic con- ditions reacts with oxygen to form nitrite (Bengtsson, 1973).

Fragments of the $a m o B$ gene from the chemolithoautotrophic nitrifier $N$. europaea were amplified by PCR using primers designed to the published sequence (McTavish et al., 1993b; Bergmann \& Hooper, 1994b). The amplification product was cloned into pUC18, and then used in hybridization experiments against pB8. Under conditions of extremely low stringency, a very weak hybridization was observed between the $a m o B$ probe and a $1.7 \mathrm{~kb}$ EcoRI-Pst I fragment derived from pB8 (data not shown; Fig. 3). For this reason, the corresponding region of the $\mathrm{Pa}$. denitrificans chromosome was disrupted to confirm that $\mathrm{pB} 8$ contains genes required for ammonia oxidation. The $1.7 \mathrm{~kb}$ EcoRI-Pst fragment from pB8 was cloned into pUC18 and the unique $S a l$ site within this fragment was disrupted with the $\Omega$ cartridge, which contains genes for streptomycin and spectinomycin resistance, flanked by transcriptional terminators (Prentki \& Krisch, 1984). The disrupted fragment was cloned into the suicide vector pGRPd1 as an EcoRI-SphI fragment (using the $S p h$ I site in pUC18), generating a plasmid designated pSAD43. This plasmid was introduced into $\mathrm{Pa}$. denitrificans by triparental conjugation, and streptomycin-resistant exconjugants were selected. Exconjugants which had acquired the $\Omega$ cartridge by a double-crossover event were initially identified on the basis of their failure to hybridize to labelled pGRPd1 DNA in a colony hybridization. Genomic DNAs were isolated from strains identified in this manner, and hybridization using the $1.7 \mathrm{~kb}$ EcoRI-PstI fragment as a probe confirmed that the genomic DNA had been disrupted by a single copy of $\Omega$ at the expected location (data not shown). Of a total of 100 exconjugants screened, three had acquired the $\Omega$ cartridge by a double-crossover event. The putative amo mutants were tested for their ability to oxidize ethene and were found to have completely lost this activity (Fig. 4). This confirms that the DNA cloned in pLCC5 does indeed contain nitrification genes. Interestingly, the amo mutant expresses wild-type levels of $\mathrm{HAO}$, as judged by Western blot analysis (data not shown). This implies that the genes encoding AMO and HAO are not in a single transcription unit, or that if they are, the gene(s) for $\mathrm{HAO}$ is promoter proximal. The nitrification mutant had no apparent phenotype when grown in aerobic batch cultures with succinate and ammonia as the carbon and nitrogen sources. A more detailed characterization of this mutant in chemostat cultures is now in progress and will allow ideas about the physiological role of heterotrophic nitrification to be tested, for the first time.

\section{Methane oxidation}

The $\alpha$-proteobacterium $M$. extorquens AM1 (ATCC 14718 ) is a pink-pigmented facultative methylotroph capable of growth on methanol but not methane (Peel \& Quayle, 1961). The cosmid pLCC5 was introduced into this strain by conjugation and exconjugants were 


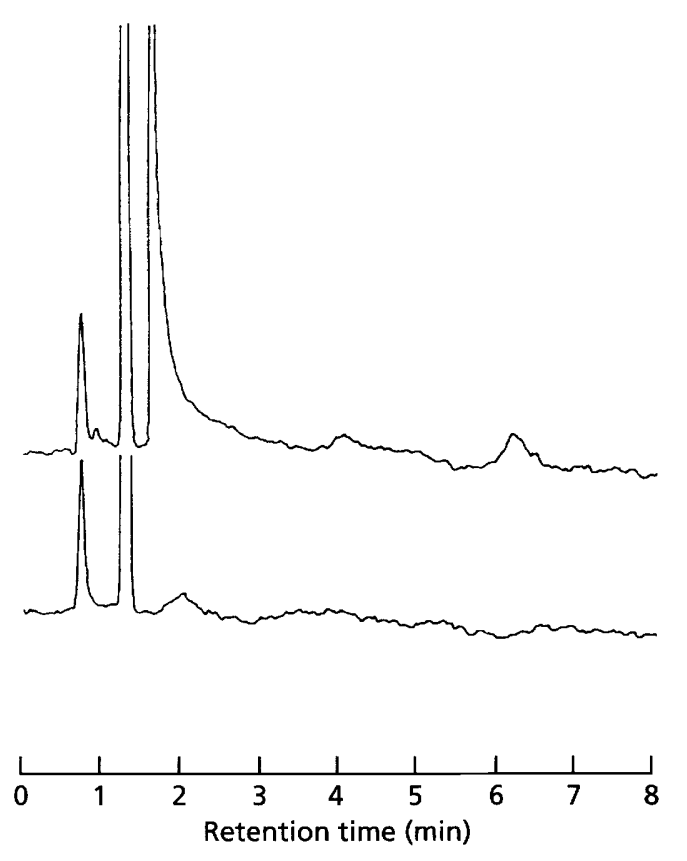

Fig. 4. Ethene oxidation by wild-type $P a$. denitrificans and a nitrification mutant. Ethene oxidation was analysed by gas chromatography as in Fig. 2. Upper trace, Pa. denitrificans Pd1222; lower trace, Pa. denitrificans amo mutant.

selected on minimal medium containing methanol as the sole carbon source and ammonia as the nitrogen source. The presence of an active AMO in these exconjugants was verified by following the oxidation of ethene in the same manner as described above for Ps. putida/pLCC5. Wild-type $M$. extorquens was incapable of oxidizing ethene. In contrast, M. extorquens/pLCC5 was found to accumulate epoxyethane to approximately $35 \mu \mathrm{M}$ in as little as $10 \mathrm{~min}$, and epoxyethane disappeared equally rapidly (data not shown). This suggests that $M$. extorquens has a pathway for the further metabolism of epoxyethane.

Since AMOs are capable of oxidizing methane, the ability of M. extorquens/pLCC5 to oxidize methane to methanol, and therefore to grow on methane, was tested. $M$. extorquens and $M$. extorquens/pLCC5 were plated onto minimal media with nitrate as the nitrogen source and no added carbon source. Plates were incubated in a $50 \%$ methane/air atmosphere at $30{ }^{\circ} \mathrm{C}$. After $9 \mathrm{~d}$ incubation, M. extorquens/pLCC 5 formed colonies whereas $M$. extorquens did not. Growth of $M$. extorquens/pLCC5 was methane-dependent since colonies did not form on plates incubated in air alone. This suggests that the AMO of $P a$. denitrificans supplied by pLCC5 is able to oxidize methane and provide methanol which is utilizable for growth by $M$. extorquens. The ability of the AMO from $\mathrm{Pa}$. denitrificans to oxidize methane is an additional biochemical similarity to the AMO of autotrophic organisms.

Gas chromatography data showed that $M$. extorquens/pLCC5 was capable of a rapid oxidation of
Table 2. Expression of AMO in $M$. extorquens allows significant growth on ethene

Growth was in liquid culture for $8 \mathrm{~d}$. Because of the poor growth and clumping of cultures of strains containing pLCC5, growth is expressed in terms of protein concentration. Data are from assays of two independent cultures.

\begin{tabular}{|llc|}
\hline Strain & Growth conditions & $\begin{array}{c}\text { Protein } \\
\left(\mu \mathrm{g} \mathrm{ml}^{-1}\right)\end{array}$ \\
\hline M. extorquens & Methanol & $140 \cdot 0$ \\
M. extorquens & Ethene & $1 \cdot 4$ \\
M. extorquens/pLCC5 & Ethene (dark) & $9 \cdot 8$ \\
M. extorquens/pLCC5 & Ethene (light) & $4 \cdot 8$ \\
M. extorquens/pLCC5 & Methanol & $24 \cdot 8$ \\
\hline
\end{tabular}

ethene to epoxyethane, and also subsequent metabolism of epoxyethane. Therefore, experiments were performed to determine whether $M$. extorquens/pLCC5 could grow on ethene, using the plasmid-encoded AMO for the initial step of ethene oxidation. $M$. extorquens/pLCC5 and M. extorquens were grown in liquid medium containing nitrate as a nitrogen source and ethene as a carbon source (ethene is soluble in water to approximately $5 \mathrm{mM}$ ). M. extorquens was incapable of growth on ethene, whereas introduction of pLCC5 permitted significant growth (Table 2). Growth was inhibited to a large extent by normal laboratory lighting, which is consistent with the fact that the purified AMO is light-sensitive (Moir et al., 1996b).

\section{Toxicity of AMO}

The increased rate of ethene oxidation by $M$. extorquens/pLCC5 as compared to Ps. putida/pLCC5 might suggest that the AMO is more highly expressed and/or more active in $M$. extorquens. Accordingly, $800 \mathrm{nmol}$ nitrite (mg protein) $)^{-1}$ was found to accumulate in cultures of $M$. extorquens/pLCC5 after $3 \mathrm{~d}$ growth, compared with $50 \mathrm{nmol} \mathrm{mg}^{-1}$ in Ps. putida/pLCC5 and $30 \mathrm{nmol} \mathrm{mg}{ }^{-1}$ in a strain of $\mathrm{Pa}$. denitrificans containing pLCC5 and deficient in nitrite reductase activity (in all cases growth was in media containing ammonia as the sole nitrogen source). Introduction of pLCC5 into $M$. extorquens caused a severe defect in growth on media containing ammonia, with cultures clumping and reaching very low yields. There was also a dramatic change in the appearance of cells in electron micrographs, which is consistent with the production of internal membranes (Fig. 5). Extensive internal membranes are seen in the autotrophic ammonia oxidizers and in methanotrophs expressing pMMO (Bock et al., 1991; Hanson \& Hanson, 1996). The cosmid was also toxic to Ps. putida, causing a threefold reduction in growth rate and yield, but there was no effect on the appearance of cells in electron micrographs (not shown). In the case of M. extorquens, the toxicity of pLCC5 was partially alleviated by growth in the light (an inhibitor of 


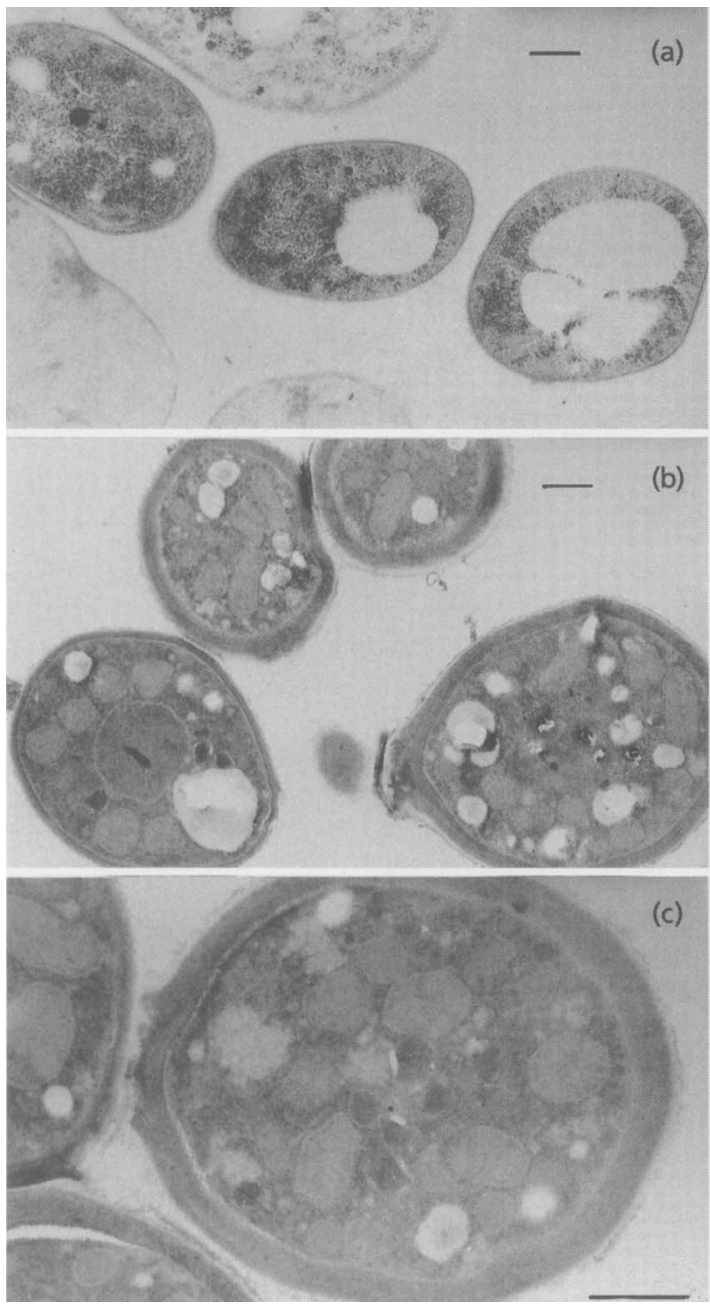

Fig. 5. Electron micrographs of $M$. extorquens (a) and $M$. extorquens/pLCC5 (b, c). Cultures were grown in media containing succinate as the carbon and energy source and ammonia as the nitrogen source. The white areas are likely to be poly- $\beta$-hydroxybutyrate. Bars, $1 \mu \mathrm{m}$.

AMO; Moir et al., 1996b) or by the use of glutamate rather than ammonia as a nitrogen source. This suggests that AMO activity is responsible for the toxicity of pLCC5, perhaps because it causes the accumulation of hydroxylamine. In Ps. putida, pLCC5 was only slightly less toxic in the presence of light, suggesting that AMO expression, rather than activity, was the major reason for toxicity in this case. This may be because Ps. putida is incapable of making the internal membranes required to accommodate the AMO.

The amo genes of N. europaea are highly toxic to E. coli and have never been cloned on the same fragment of DNA or heterologously expressed (Bergmann \& Hooper, 1994b). However, pLCC5 is not toxic to E. coli. Cell-free extracts of E. coli/pLCC5 and E. coli/pLAFR3 were separated on SDS-PAGE and transferred to nitrocellulose membranes which were probed with an anti-
$\mathrm{HAO}$ antiserum. No immunologically cross-reacting polypeptide of $18.5 \mathrm{kDa}$ was detectable in either extract, indicating that the bao gene(s) are not expressed from pLCC5 in E. coli, which is probably because their promoters are not active in E. coli. This being the case, it is likely that the amo genes are also not expressed from pLCC5. Failure to express the nitrification genes probably accounts for the non-toxicity of pLCC5 in E. coli. However, pB8 was toxic to E. coli, causing cells to clump and grow at a much reduced rate. Furthermore, subclones from the left end of the insert in pB8 (Fig. 3) could not be isolated, which may indicate that this region of DNA is especially toxic. The reasons for the increased toxicity of some subclones are not clear at this time, but copy number effects and expression from vector promoters are possible explanations.

\section{Concluding remarks}

The isolation of heterotrophic nitrification genes and the recent purification of AMO and HAO (Moir et al., 1996b; Wehrfritz et al., 1993) represent the first steps in the molecular and biochemical characterization of this process. The genes encoding an AMO have now been expressed in a heterologous host for the first time. This has not been possible for either AMO from the autotrophic nitrifiers or pMMO from the methanotrophs, since their genes are toxic and have not been cloned on a single piece of DNA (Bergmann \& Hooper, 1994b; Semrau et al., 1995). The amo genes from $\mathrm{Pa}$. denitrificans and $N$. europaea appear to be rather different since only a very weak cross-hybridization is evident. Thus the amo genes of N. europaea are more closely related to the pmo genes, to which they hybridize at high stringency (Holmes et al., 1995; Semrau et al., 1995), than they are to the amo genes of $P$ a. denitrificans. Also, degenerate PCR primers which amplify amo sequences from autotrophic nitrifiers and $p m o$ sequences from methanotrophs do not amplify amo from $P a$. denitrificans (Holmes et al., 1995). An additional distinction is that the amo and hao genes of $\mathrm{Pa}$. denitrificans are present in the genome in single linked copies (hybridization experiments have indicated no evidence of gene duplication), whereas the N. europaea genes are unlinked and are present in multiple copies. Nevertheless, the AMO of $\mathrm{Pa}$. denitrificans has some notable similarities to that of the autotrophic ammonia oxidizers, particularly the ability to oxidize alkenes, the apparent requirement for copper, and inhibition by light, diethyldithiocarbamate and allylthiourea (Moir $e t$ al., 1996b). In the light of these similarities and differences, determination of the primary structure of the $P a$. denitrificans AMO will be especially interesting.

\section{ACKNOWLEDGEMENTS}

This work was supported by BBSRC grants to D. J.R. and S.S. L. C. C. was the recipient of an SERC Earmarked Studentship. We are grateful to Josa-Marie Wehrfritz for preparing $N$. europaea genomic DNA, Lynda Flegg for technical assistance, and Rick Evans-Gowing for electron microscopy. 


\section{REFERENCES}

Arciero, D. M. \& Hooper, A. B. (1993). Hydroxylamine oxidoreductase from Nitrosomonas europaea is a multimer of an octaheme subunit. J Biol Chem 268, 14645-14654.

Arciero, D. M., Balny, C. \& Hooper, A. B. (1991). Spectroscopic studies of reduction of cytochrome $c_{554}$ by hydroxylamine oxidoreductase from Nitrosomonas europaea. Biochemistry 30, 11466-11472.

Arciero, D. M., Hooper, A. B., Cai, M. \& Timkovich, R. (1993). Evidence for the structure of the active site heme P460 in hydroxylamine oxidoreductase of Nitrosomonas. Biochemistry 32, 9370-9378.

Bell, L. C., Richardson, D. J. \& Ferguson, S. J. (1990). Periplasmic and membrane-bound respiratory nitrate reductases in Thiosphaera pantotropha. FEBS Lett 265, 85-87.

Bengtsson, G. (1973). A kinetic study of the reaction between iron (III) and hydroxylamine in strongly acid percholate solutions. Acta Chem Scand 27, 1717-1724.

Bergmann, D. J. \& Hooper, A. B. (1994a). The primary structure of cytochrome $\mathrm{P}_{460}$ of Nitrosomonas europaea: presence of a $\mathrm{c}$ heme binding motif. FEBS Lett 353, 324-326.

Bergmann, D. J. \& Hooper, A. B. (1994b). Sequence of the gene, amoB, for the $43-\mathrm{kDa}$ polypeptide of ammonia monooxygenase of Nitrosomonas europaea. Biochem Biophys Res Commun 204, 759-762.

Berks, B. C., Moir, J. W. B., Ferguson, S. J. \& Richardson, D. J. (1995). Enzyme and associated electron transfer systems that catalyse the respiratory reduction of nitrogen oxides and oxyanions. Biochim Biophys Acta 1232, 97-173.

Bock, E., Koops, H.-P., Harms, H. \& Ahlers, B. (1991). The biochemistry of nitrifying organisms. In Variations in Autotrophic Life, pp. 171-200. Edited by J. M. Shively \& L. L. Barton. London: Academic Press.

Bradford, M. M. (1976). A rapid and sensitive method for the quantitation of microgram quantities of protein utilizing the principle of protein-dye binding. Anal Biochem 72, 248-254.

Burnette, W. N. (1981). Western blotting: electrophoretic transfer of proteins from sodium dodecyl-polyacrylamide gels to unmodified nitrocellulose and radiographic detection with antibody and radioiodinated protein A. Anal Biochem 112, 195-203.

Burrows, K. J., Cornish, A, Scott, D. \& Higgins, I. J. (1984). Substrate specificities of the soluble and particulate methane monooxygenases of Methylosinus trichosporium OB3b. J Gen Microbiol 130, 3327-3333.

Colby, J., Stirling, D. I. \& Dalton, H. (1977). The soluble methane monooxygenase of Methylococcus capsulatus (Bath). Its ability to oxygenate $\mathrm{n}$ alkanes, $\mathrm{n}$ alkenes, ethers and alicyclic, aromatic and heterocyclic compounds. Biochem J 165, 395-402.

Coleman, J. K., Cornish-Bowden, A. \& Cole, J. A. (1978). Purification and properties of nitrite reductase from Escherichio coli K12. Biochem J 175, 483-493.

Ensign, S. A., Hyman, M. R. \& Arp, D. J. (1993). In vitro activation of the ammonia monooxygenase by copper. J Bacteriol 175, 1971-1980.

Figurski, D. H. \& Helinski, D. R. (1979). Replication of an origincontaining derivative of plasmid RK2 dependent on a plasmid function provided in trans. Proc Natl Acad Sci USA 76, $1648-1652$

Glaser, J. H. \& DeMoss, J. A. (1971). Phenotypic restoration by molybdate of nitrate reductase activity in $c h l D$ mutants of Escherichia coli. J Bacteriol 108, 854-860.
Hanson, R. S. \& Hanson, T. E. (1996). Methanotrophic bacteria. Microbiol Rev 60, 439-471.

Harms, N. E., de Vries, G. E., Maurer, K., Veltkamp, E. \& Stouthamer, A. H. (1985). Isolation and charcterization of Paracoccus dentrificans mutants with defects in the metabolism of one-carbon compounds. J Bacteriol 164, 1064-1070.

Holmes, A. J., Costello, A., Lidstrom, M. E. \& Murrell, J. C. (1995). Evidence that the particulate methane monooxygenase and the ammonia monooxygenase may be evolutionarily related. FEMS Microbiol Lett 132, 203-208.

Hommes, N. G., Sayavedra-Soto, L. A. \& Arp, D. J. (1994). Sequence of $b c y$, a gene encoding cytochrome $c-554$ from Nitrosomonas europaea. Gene 146, 87-89.

Hyman, M. R. \& Wood, P. M. (1984). Ethylene oxidation by Nitrosomonas europaea. Arch Microbiol 137, 155-158.

Igarashi, N., Moriyama, H., Fujiwara, T., Fukumori, Y. \& Tanaka, N. (1997). The $2 \cdot 8 \AA$ structure of hydroxylamine oxidoreductase from a nitrifying chemoautotrophic bacterium, Nitrosomonas europaea. Nat Struct Biol 4, 276-284.

Keen, N. T., Tamaki, S., Kobayashi, D. \& Trollinger, D. (1988). Improved broad-host range plasmids for DNA cloning in Gramnegative bacteria. Gene 70, 191-197.

Keener, W. K. \& Arp, D. J. (1994). Transformations of aromatic compounds of Nitrosomonas europaea. Appl Environ Microbiol 60, 1914-1920.

Klotz, M. G., Alzerreca, J. \& Norton, J. M. (1997). A gene encoding a membrane protein exists upstream of the $a m o A / a m o B$ genes in ammonia oxidising bacteria : a third member of the amo operon? FEMS Microbiol Lett 150, 65-73.

McTavish, H., Laquier, F., Arciero, D., Logan, M., Mundfrom, G., Fuchs, J. A. \& Hooper, A. B. (1993a). Multiple genes encoding electron transport proteins in the bacterium Nitrosomonas europaea. J Bacteriol 175, 2445-2447.

McTavish, H., Fuchs, J. A. \& Hooper, A. B. (1993b). Sequence of the gene coding for ammonia monooxygenase in Nitrosomonas europaea. J Bacteriol 175, 2436-2444.

Moir, J. W. B., Wehrfritz, J.-M., Spiro, S. \& Richardson, D. J. (1996a). The biochemical characterisation of a novel non-haemiron hydroxylamine oxidase from Paracoccus denitrificans GB17. Biochem J 319, 823-827.

Moir, J. W. B., Crossman, L. C., Spiro, S. \& Richardson, D. J. (1996b). The purification of ammonia monooxygenase from Paracoccus denitrificans. FEBS Lett 387, 71-74.

Nguyen, H.-H.T., Shiemke, A. K., Jacobs, S. J., Hales, B. J., Lidstrom, M. E. \& Chan, S. I. (1994). The nature of the copper ions in the membranes containing the particulate methane monooxygenase from Methylococcus capsulatus (Bath). J Biol Chem 269, 14995-15005.

Nguyen, H.-H. A. T., Zhu, M., Elliot, S. J. \& 11 other authors (1996). The biochemistry of the particulate methane monooxygenase. In Microbial Growth on $C_{1}$ Compounds, pp. 150-158. Edited by M. E. Lidstrom \& F. R. Tabita. Dordrecht: Kluwer Academic.

Peel, D. \& Quayle, J.R. (1961). Microbial growth on $C_{1}$ compounds: isolation and characterization of Pseudomonas AM1. Biochem J 81, 465-469.

Prentki, P. \& Krisch, H. M. (1984). In vitro insertional mutagenesis with a selectable DNA fragment. Gene 29, 303-313.

Robertson, L. A. \& Kuenen, J. G. (1983). Thiosphaera pantotropha gen. nov. sp. nov., a facultatively anaerobic, facultatively 
autotrophic sulphur bacterium. J Gen Microbiol 129, 28472855.

Robertson, L. A. \& Kuenen, J. G. (1988). Heterotrophic nitrification in Thiosphaera pantotropha: oxygen uptake and enzyme studies. J Gen Microbiol 134, 857-863.

Robertson, L. A. \& Kuenen, J. G. (1990a). Physiological and ecological aspects of aerobic denitrification, a link with heterotrophic nitrification? In Denitrification in Soil and Sediment, pp. 91-104. Edited by N. P. Revsbech \& J. Sorenson. New York: Plenum.

Robertson, L. A. \& Kuenen, J. G. (1990b). Combined heterotrophic nitrification and denitrification in Thiosphaera pantotropha and other bacteria. Antonie Leeuwenhoek 57, 137-152.

Sambrook, J., Fritsch, E. F. \& Maniatis, T. (1989). Molecular Cloning: a Laboratory Manual, 2nd edn. Cold Spring Harbor, NY: Cold Spring Harbor Laboratory.

Sayavedra-Soto, L. A., Hommes, N. G. \& Arp, D. J. (1994). Characterisation of the gene encoding hydroxylamine oxidoreductase in Nitrosomonas europaea. J Bacteriol 176, 504-510.

Semrau, J. D., Chistoserdov, A., Lebron, J., Castello, A., Davagnino, J., Kenna, E., Holmes, A. J., Finch, R., Murrell, J. C. \& Lidstrom, M. E. (1995). Particulate methane monooxygenase genes in methanotrophs. J Bacteriol 177, 3071-3079.

van Spanning, R. J. M., Wansell, C. W., Reijnders, W. N. M., Harms, H., Ras, J., Oltmann, L. F. \& Stouthamer, A. H. (1991). A method for introduction of unmarked mutations in the genome of Paracoccus denitrificans: construction of strains with multiple mutations in the genes encoding periplasmic cytochromes $c_{550}$, $c_{551 \mathrm{i}}$, and $c_{553 \mathrm{i}} . J$ Bacteriol 173, 6962-6970.

Staskawicz, B., Dahlberg, D., Keen, N. T. \& Napoli, C. (1987). Molecular characterisation of cloned avirulence genes from race 0 and race 1 of Pseudomonas syringae p $v$. glycinea. J Bacteriol 169, 5789-5794.

Stirling, D. I. \& Dalton, H. (1979). Properties of the methane monooxygenase from extracts of Methylosinus trichosporium OB3b. Eur J Biochem 96, 205-212.

Wehrfritz, J.-M., Reilly, A., Spiro, S. \& Richardson, D. J. (1993). Purification of hydroxylamine oxidoreductase from Thiosphaera pantotropha. Identification of electron acceptors that couple heterotrophic nitrification to aerobic denitrification. FEBS Lett 335, 246-250.

Yanisch-Perron, C., Vieira, J. \& Messing, J. (1985). Improved M13 phage cloning vectors and host strains: nucleotide sequences of the M13mp18 and pUC19 vectors. Gene 33, 103-119.

Zahn, J.A. \& DiSpirito, A. A. (1996). Membrane-associated methane monooxygenase from Methylococcus capsulatus (Bath). J Bacteriol 178, 1018-1029.

Zahn, J. A., Duncan, C. \& DiSpirito, A. A. (1994). Oxidation of hydroxylamine by cytochrome P-460 of the obligate methylotroph Methylococcus capsulatus Bath. J Bacteriol 176, 5879-5887.

Received 16 June 1997; revised 22 August 1997; accepted 29 August 1997. 